\title{
Effect of Curing on the Tensile and Flexural Performance of Fully Biodegradable Corn Starch/Areca Frond Composites
}

\author{
Srinivas Shenoy Heckadka, Suhas Yeshwant Nayak, Manjeshwar Vijaya Kini, \\ Revati Chowgule, and Pranay Jain \\ Department of Mechanical and Manufacturing Engineering, Manipal Institute of Technology, Manipal University, \\ Manipal 576104, India
}

Correspondence should be addressed to Suhas Yeshwant Nayak; synayak@gmail.com

Received 22 June 2015; Revised 6 August 2015; Accepted 9 August 2015

Academic Editor: Sandro C. Amico

Copyright (C) 2015 Srinivas Shenoy Heckadka et al. This is an open access article distributed under the Creative Commons Attribution License, which permits unrestricted use, distribution, and reproduction in any medium, provided the original work is properly cited.

\begin{abstract}
Composites have monopolized the automotive, construction, and packaging industry. Their high strength to weight ratio has made them an integral part of numerous engineering applications. In this study biodegradable matrix is combined with areca frond fibres for developing composites for low strength structural applications. Areca frond fibres were extracted and treated with sodium bicarbonate to improve the surface characteristics. Hand lay-up and compression moulding techniques were used to fabricate composites having unidirectional fibre orientation. The specimens prepared were exposed to varied environments, namely, sunlight, OTG oven, steam oven, and hot air oven, for curing and the results were analyzed to best suit the implicated requirements. Scanning electron microscopy was used to observe the changes in surface characteristics of the frond fibres after treatment. Tensile and flexural strength of starch based/areca frond reinforced composites were evaluated according to ASTM standards. Test results revealed that composites cured in a steam oven resulted in improved tensile and flexural strength compared to other curing environments.
\end{abstract}

\section{Introduction}

Composites have been used by mankind since prehistoric times. Straw reinforced clay bricks, bamboo shoots reinforced mud walls, and swords made out of laminated metals are some of the evidences for it [1]. Composites have their ability to be formed into any desired shape with excellent dimensional stability and high strength to weight ratios. They are cost effective substitutes for materials requiring high maintenance. Customized surface finish can be obtained with good resistance to heat, chemicals, and corrosion. In addition it is also resistant to creep and has exceptional electrical insulation when required $[2,3]$. Natural fibre reinforced biodegradable polymers have great scope in the engineering field. Their development is independent of petroleum based products and so it makes a good green material [4]. Agriculture crop residues can be used as reinforcement materials to improve mechanical strength and heat resistance. In the past several decades, biodegradable products have experienced a revival, with an exponential increase in production having high commercial value.

Srinivasababu et al. [5] explored the possibility of using okra as reinforcement for polyester resin and noticed that the tensile strength and modulus of untreated and treated samples were found to be higher than the pure polyester specimens. Nishino et al. [6] carried out a study on kenaf fibre reinforced PLA composites. They observed that the composite possesses superior mechanical and thermal properties. Paralleled to this, Ochi [7] demonstrated the tensile and flexural strengths of kenaf reinforced composites. Many such composites fabricated display their potential as an alternative to traditional composites and have become an integral part of the electrical, medical, and construction industry.

Swamy et al. [8] in their study determined the strength of areca nut fibres treated with alkali which exhibited excellent resistance to moisture compared to wood based boards making them a very promising material in the packaging industry. Zhang et al. [9] studied the synthesis and characterization 


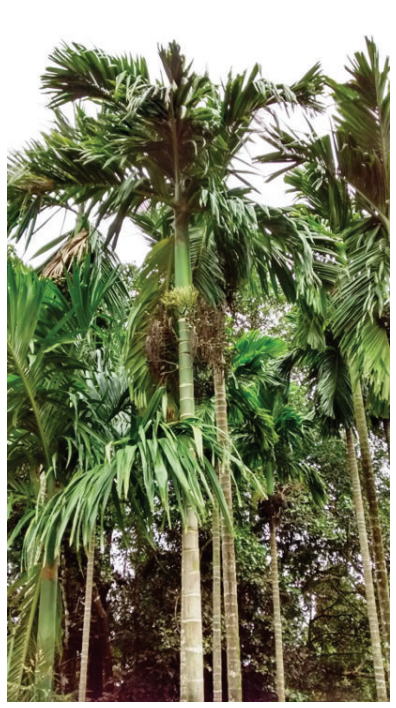

(a)

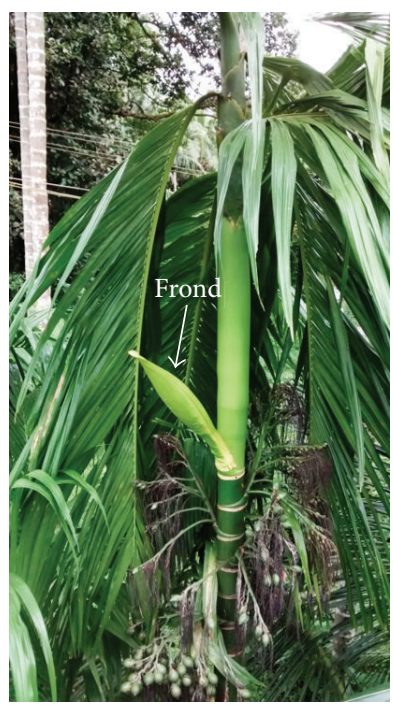

(b)

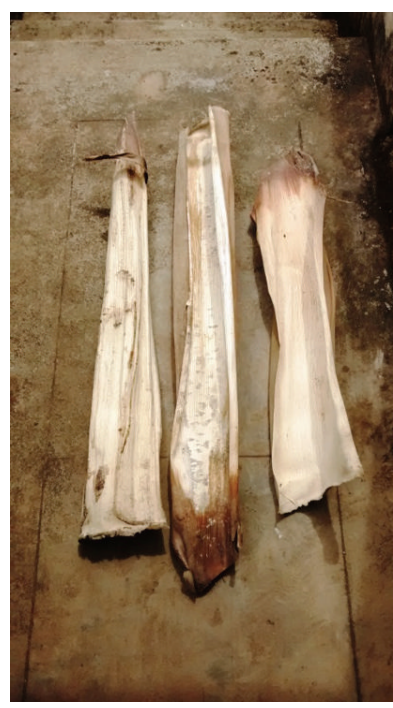

(c)

FIgURE 1: (a) Areca palm, (b) areca frond, and (c) dried areca frond.

of polyvinyl alcohol (PVA), nanohydroxyapatite (HA), and natural silk composite hydrogel using repeated freezing and thawing method based on Taguchi technique. Results showed that the formula of polyvinyl alcohol, nanohydroxyapatite, and silk composite hydrogel with PVA 15\%, HA 2.0\%, and silk $1.0 \%$ mass percentage was the best. Qiao et al. [10] studied composites made from poly(ethylene-co-vinyl alcohol), polypropylene carbonate, calcium carbonate, and starch fabricated using melt blending. The authors observed an increase in tensile strength with increase in starch content.

Heckadka et al. [11] used Taguchi technique to study the flexural strength of the areca frond fibres reinforced with starch, methyl cellulose, resorcinol, and glycerol based matrix material using hand lay-up/compression moulding technique. The authors reported that glycerol as plasticizer had maximum effect on the flexural strength of the composites.

Majdzadeh-Ardakani and Nazari [12] investigated the effects of the ingredients, namely, starch, poly(vinyl alcohol), and clay, to understand clay intercalation and mechanical properties.

Starch and cellulose based polymers have been used in the past for furniture, structural panels, and gardening equipment. Green composites result from a combination of a biodegradable polymer and biodegradable fillers, usually biofibres. Their production is generally based on renewable resources and their waste can be managed in an eco-friendly way in terms of lower emissions and energy consumptions [13]. These incentives have pushed researchers to dwell deep into the possibilities of tapping the raw materials available in abundance to us and shifting from the synthetic trend.

Present work is aimed at developing unidirectional laminates fabricated with areca frond fibres and corn starch based matrix to evaluate their characteristics based on different curing methods. Varied curing techniques are adopted and their tensile and flexural strengths are determined. The laminates obtained display immense potential in the packaging industry as well as for low strength applications including stationaries.

\section{Experimental Details}

2.1. Materials. The areca frond fibres used in this study were obtained from local plantations. Areca frond is a part of the tree which covers bunch of areca nuts. These trees belong to family Palmaceae. Coastal Karnataka is the main source for these fronds. The palm tree measures around $20 \mathrm{~m}$ in height with a trunk diameter of around $0.4 \mathrm{~m}$ [14]. The fronds resemble a boat hull and have dimensions of around $0.25 \mathrm{~m}$ in width and $1.5 \mathrm{~m}$ in length and have a depth of $0.1 \mathrm{~m}$. The areca palm tree, raw frond, and dried fronds are shown in Figure 1. The matrix ingredients were corn starch, water, and vinegar as base materials, methyl cellulose and resorcinol as binders, and glycerol as plasticizer. Table 1 shows the detailed specifications of the matrix ingredients.

2.2. Fibre Extraction and Treatment. Areca fronds were soaked in water for about seven days in a tank as shown in Figure 2. The $\mathrm{pH}$ of water was monitored on regular basis using digital $\mathrm{pH}$ meter to dispose it safely. For precautionary measures water was changed after every two days.

The leaves became soggy in nature after soaking from which the fibres were extracted using metal wire brush by moving it in the longitudinal direction. After the extraction of individual strands the membrane covering it was extracted using bare hands to get untreated fibres. Fibres obtained were treated with sodium bicarbonate $\left(\mathrm{NaHCO}_{3}\right)$ to get rid of fleshy membrane and impurities to enhance their physical properties. The treatment was carried out for duration of 8 hours. Solutions with three different molarities, namely, $0.3 \mathrm{M}, 0.5 \mathrm{M}$, and $1 \mathrm{M}$, were used. During the course of the treatment, $\mathrm{pH}$ of the solution was monitored and recorded at regular intervals. 


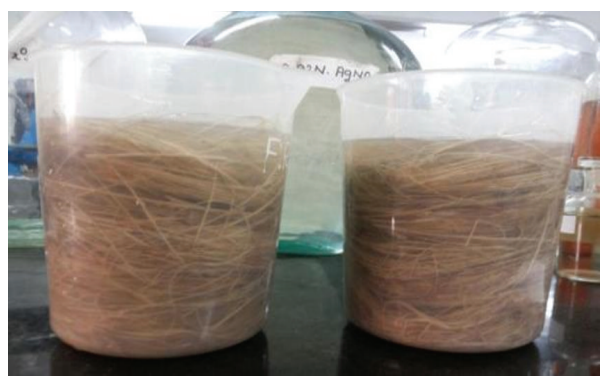

(a)

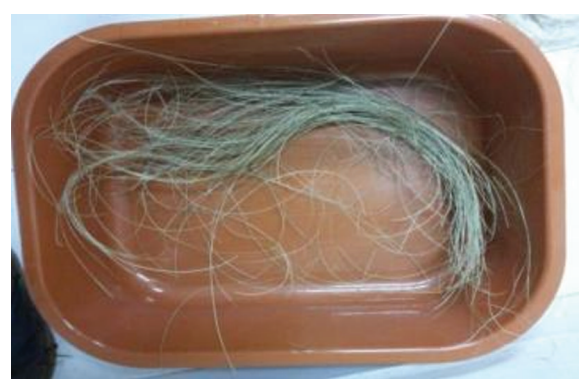

(b)

FIgURE 2: (a) Fibre treatment. (b) Treated fibres.

TABLE 1: Specifications of the matrix ingredients

\begin{tabular}{|c|c|}
\hline Name & Description \\
\hline \multicolumn{2}{|c|}{ Base material specification } \\
\hline (a) Corn starch & Edible maize starch \\
\hline Manufacturer & $\begin{array}{l}\text { Manibhadra Food Products, Hubli, } \\
\text { Karnataka }\end{array}$ \\
\hline Ingredients & $25 \%$ amylose and $75 \%$ amylopectin \\
\hline (b) Water & Normal tap water/potable water \\
\hline (c) Vinegar & Edible cooking vinegar \\
\hline Manufacturer & $\begin{array}{l}\text { Aditi Foods Private Ltd., Sangli, } \\
\text { Maharashtra }\end{array}$ \\
\hline Ingredients & Acetic acid and water \\
\hline \multicolumn{2}{|r|}{ Binder specification } \\
\hline (a) Methyl cellulose & $300-560 \mathrm{cps}$ purified \\
\hline Manufacturer & Merck Specialities Private Ltd., Mumbai \\
\hline Ingredients & $\begin{array}{l}\text { Cellulose, sodium hydroxide, methyl } \\
\text { chloride }\end{array}$ \\
\hline (b) Resorcinol & Recrystalline extra pure \\
\hline Manufacturer & Merck Specialities Private Ltd., Mumbai \\
\hline Ingredients & $\begin{array}{l}\text { Assay, chloride, sulfate, water, and } \\
\text { sulfated ash }\end{array}$ \\
\hline \multicolumn{2}{|r|}{ Plasticizer specification } \\
\hline (a) Glycerol & $98 \%$ purified \\
\hline Manufacturer & Merck Specialities Private Ltd., Mumbai \\
\hline Ingredients & $\begin{array}{l}\text { Assay, acid, alkali, chloride, sulfate, water, } \\
\text { and sulfated ash }\end{array}$ \\
\hline
\end{tabular}

TABLE 2: Average diameter of areca frond fibres.

\begin{tabular}{lcccc}
\hline Description/molarity & Untreated & $0.3 \mathrm{M}$ & $0.5 \mathrm{M}$ & $1 \mathrm{M}$ \\
\hline Diameter $(\mathrm{mm})$ & 0.415 & 0.382 & 0.363 & 0.349 \\
\hline
\end{tabular}

\subsection{Preparation of Test Samples of Areca Fibres and Composite} Laminates. Treated areca frond fibres were cut to a length of $60 \mathrm{~mm}$. Diameter of the fibres was measured using a digital micrometer nearest to $0.001 \mathrm{~mm}$ at different locations on a single fibre. Measurements were taken on fifty fibres to arrive at an average. The average diameters of the fibres are tabulated in Table 2.
TABLE 3: Curing environments and parameters.

\begin{tabular}{lcc}
\hline \multirow{2}{*}{ Curing environment } & \multicolumn{2}{c}{ Curing parameters } \\
& Temperature $\left({ }^{\circ} \mathrm{C}\right)$ & Duration $(\mathrm{h})$ \\
\hline Sunlight & 38 & 8 \\
OTG oven & 80 & 4 \\
Steam oven & 80 & 4 \\
Hot air oven & 80 & 4 \\
\hline
\end{tabular}

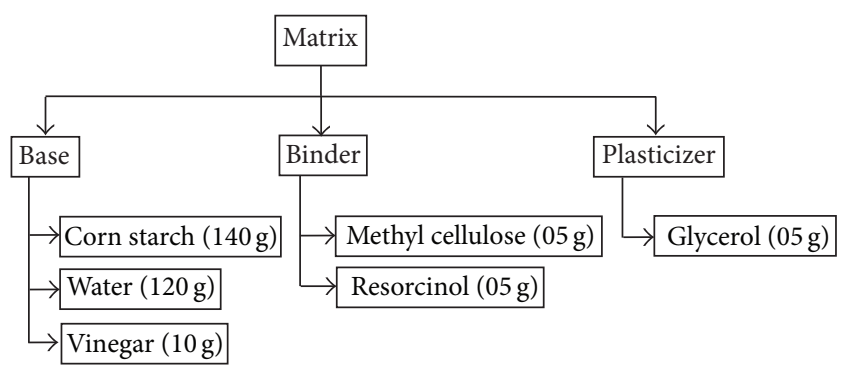

FIGURE 3: Ingredients of the biodegradable matrix.

Figure 3 shows the basic ingredients of the matrix. The matrix ingredients were weighed to the nearest $1 \mathrm{mg}$. The weighed constituents were mixed in a vessel using a magnetic stirrer. Plasticizer and binders were added and stirred for 20 minutes. The mix is then transferred to a bowl and heated at $140^{\circ} \mathrm{C}$. Heating is continued till it transforms to a semisolid state. The fibres are kept aligned in a single direction in a mould of $250 \mathrm{~mm} \times 250 \mathrm{~mm}$ dimension. The matrix mix was transferred to the mould and spread evenly using a roller to facilitate escape of air from the matrix to prevent voids in the composite. Compacting can be achieved using several techniques. In the present work, in-house fabricated pneumatic press was used for compaction of the unidirectional laminate [15]. The mould is coated with a releasing agent to prevent sticking of the composite. The composites were next cured in four various environments, namely, sunlight, OTG oven, steam oven, and hot air oven. The average thickness of all the laminates was $4 \mathrm{~mm}$. Table 3 presents details of curing and Figure 4 presents the laminates cured in different environment. 


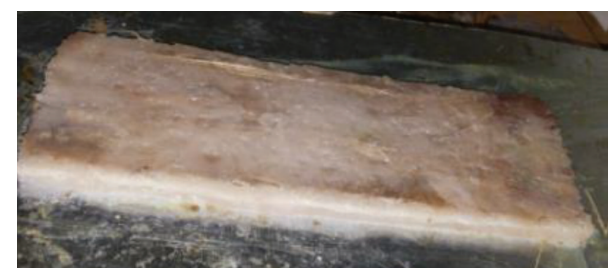

(a)

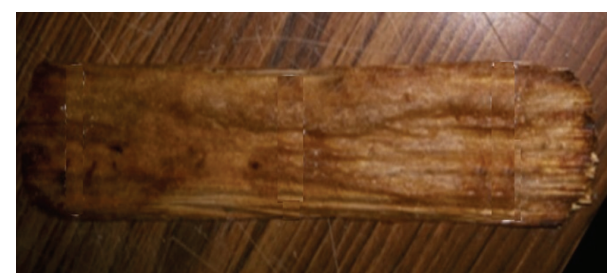

(c)

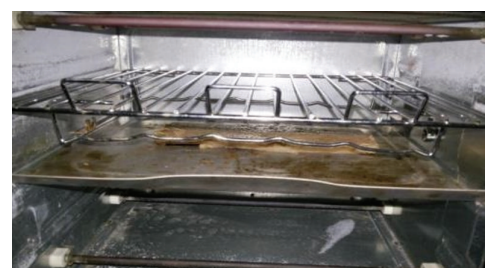

(b)

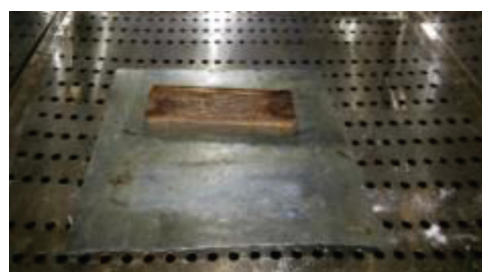

(d)

FIGURE 4: Laminates cured in different environments: (a) sunlight, (b) OTG, (c) steam, and (d) hot air.

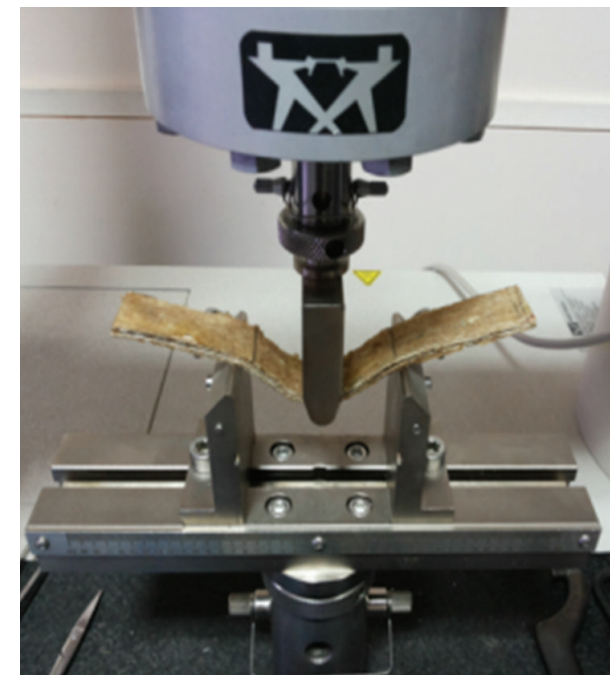

(a)

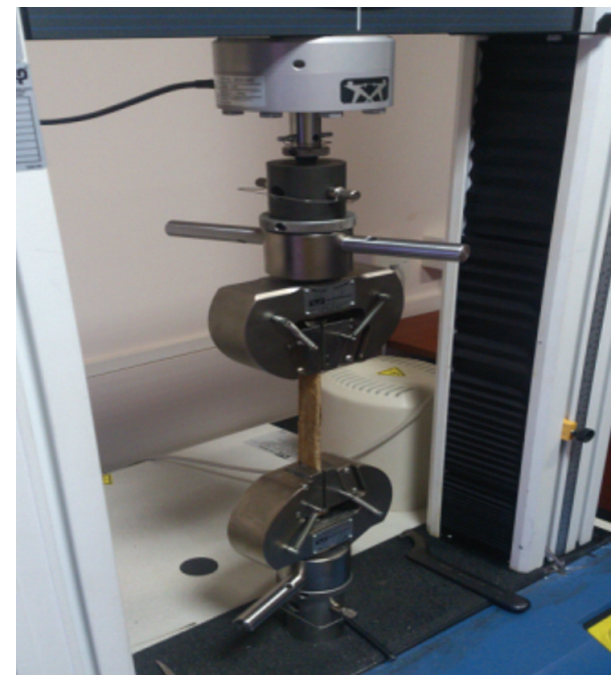

(b)

Figure 5: Test setup. (a) Tensile test and (b) flexural test.

2.4. Mechanical Properties of Fibre and Composites. Tensile test of single fibre was evaluated on Universal Testing Machine (UTM) of Instron Make (model 3366). The tests were conducted according to ASTM C1557 [16] at a constant crosshead speed of $1 \mathrm{~mm} / \mathrm{min}$ and gauge length of $30 \mathrm{~mm}$ [17]. Fibres from all the categories, namely, untreated, $0.3 \mathrm{M}$, $0.5 \mathrm{M}$, and $1 \mathrm{M}$, were tested and, to arrive at a mean, five fibres from each category were selected. Composite specimens for tensile test were cut from the cured laminates to a size of $250 \times 25 \times 4 \mathrm{~mm}$. The tests were conducted on Instron UTM at a constant crosshead speed of $2 \mathrm{~mm} / \mathrm{min}$ according to ASTM D3039 [18]. Tensile strength was obtained from the data acquisition computer which recorded the load and displacement. Flexural tests were conducted to determine the bending strength of the laminates. Procedure A (three-point bending) of ASTM D790 [19] was adopted and the tests were carried out at a constant crosshead speed of $2 \mathrm{~mm} / \mathrm{min}$ on
Instron UTM. The dimension of the flexural test specimen was $78 \times 13 \times 4 \mathrm{~mm}$. Five specimens of each curing condition were tested. The test setup is presented in Figure 5.

2.5. Scanning Electron Microscopy (SEM). The surface of the areca frond fibres was examined using Zeiss Make scanning electron microscope (model: Zeiss EVO 18, Germany). Prior to analysis of areca frond fibres, samples were coated with a thin layer of silver by ion sputtering to prevent charging of the specimen. An accelerating voltage of $15 \mathrm{kV}$ was used. The SEM micrographs were used to assess the effectiveness of treatment and to decide the suitable concentration of the treating medium.

\section{Results and Discussion}

3.1. Effect of Treatment on the Surface Characteristics of Areca Frond Fibres. SEM images of the fibres are shown in 


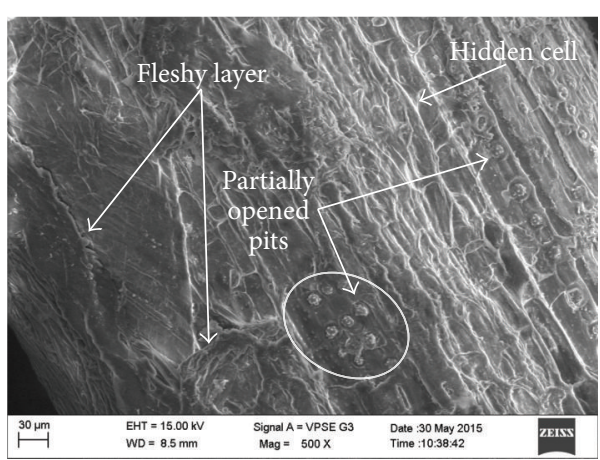

(a)

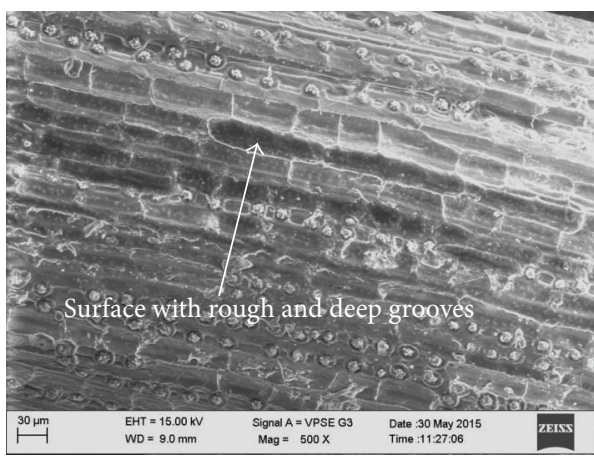

(c)

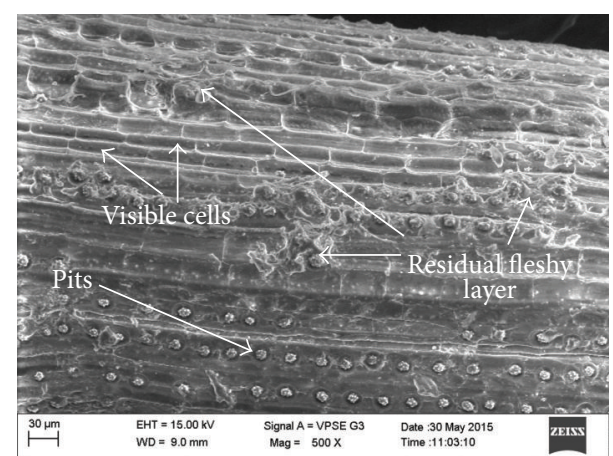

(b)

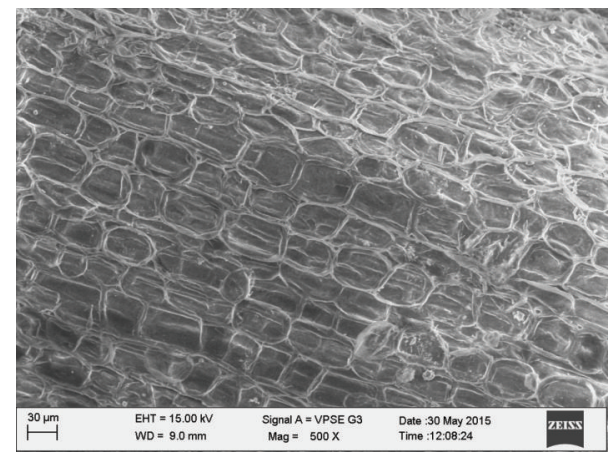

(d)

Figure 6: SEM micrographs of (a) untreated fibre, (b) fibre treated with $0.3 \mathrm{M} \mathrm{NaHCO}_{3}$, (c) fibre treated with $0.5 \mathrm{M} \mathrm{NaHCO}_{3}$, and (d) fibre treated with $1 \mathrm{M} \mathrm{NaHCO}_{3}$.

Figures 6(a)-6(d). Figure 6(a) shows the micrograph of the untreated areca frond fibre. From this micrograph, it can be seen that a fleshy layer covers the fibre beneath which lies cells and pits aligned along the axis of the fibre. Treating the fibres helps in removing this fleshy layer thereby exposing the cells and pits making the surface rough. Research work in the past [20-22] has proved that rough surface of the fibre, free from any oily, fleshy, or waxy layer, improves the surface interaction between it and the matrix. Figures $6(\mathrm{~b})-6(\mathrm{~d})$ show the surface of the treated fibres. From these micrographs, it is evident that as the concentration of the treating solution increases, surface roughness of the fibre increases forming grooves. This is due to removal of the fleshy material that covers the fibre. With removal of fleshy material, pits and cells become more prominent. Treating with $1 \mathrm{M}$ solution of sodium bicarbonate caused excessive removal of material from the fibre surface resulting in disappearance of pits leaving behind a wellconnected network of cells with decreased wall thickness. Excessive removal of material weakens the fibre making it unsuitable for use.

3.2. Tensile Properties of Areca Frond Fibres. Table 4 presents the tensile strength of areca frond fibres. It was observed that the tensile strength of untreated fibre was greater than that of treated fibres. Higher concentration of sodium bicarbonate ( $1 \mathrm{M})$ reduces the strength by about $47 \%$ and $36 \%$ when compared to concentrations of $0.3 \mathrm{M}$ and $0.5 \mathrm{M}$, respectively. Among the treated fibres, the highest tensile strength of
TABLE 4: Tensile strength of areca frond fibres.

\begin{tabular}{lcccc}
\hline Description/molarity & Untreated & $0.3 \mathrm{M}$ & $0.5 \mathrm{M}$ & $1 \mathrm{M}$ \\
\hline Tensile strength $(\mathrm{MPa})$ & 67.86 & 63.54 & 58.93 & 43.22 \\
\hline
\end{tabular}

TABLE 5: Tensile properties of composites.

\begin{tabular}{lccc}
\hline $\begin{array}{l}\text { Curing } \\
\text { environment }\end{array}$ & $\begin{array}{c}\text { Maximum } \\
\text { load }(\mathrm{N})\end{array}$ & $\begin{array}{c}\text { Maximum } \\
\text { tensile extension } \\
(\mathrm{mm})\end{array}$ & $\begin{array}{c}\text { Average } \\
\text { tensile stress } \\
(\mathrm{MPa})\end{array}$ \\
\hline Sunlight & 1260.63 & 2.48 & 12.60 \\
OTG oven & 1803.39 & 2.73 & 18.03 \\
Steam oven & 2431.17 & 4.10 & 24.31 \\
Hot air oven & 2103.54 & 3.44 & 21.03 \\
\hline
\end{tabular}

63.54 MPa was observed for fibres treated with $0.3 \mathrm{M}$ solution while the lowest tensile strength was noticed for fibres treated with $1 \mathrm{M}$ solution. However, untreated fibres exhibited higher tensile strength $(67.86 \mathrm{MPa})$ than the treated fibres. This is due to the fact that treatment leads to weakening of the fibres as a result of removal of the outer layer along with impurities and fleshy matter. Considering the surface characteristics and strength aspects, fibre treated with $0.5 \mathrm{M}$ solution was selected for this study.

3.3. Tensile and Flexural Properties of the Composites. The variation in tensile strength is shown in Table 5 and Figure 7. 
TABLE 6: Flexural properties of composites.

\begin{tabular}{lccc}
\hline $\begin{array}{l}\text { Curing } \\
\text { environment }\end{array}$ & $\begin{array}{c}\text { Maximum } \\
\text { load (N) }\end{array}$ & $\begin{array}{c}\text { Maximum } \\
\text { flexural } \\
\text { extension }(\mathrm{mm})\end{array}$ & $\begin{array}{c}\text { Average } \\
\text { flexural stress } \\
(\mathrm{MPa})\end{array}$ \\
\hline Sunlight & 34.79 & 14.24 & 16.06 \\
OTG oven & 48.07 & 6.34 & 22.19 \\
Steam oven & 73.99 & 8.29 & 34.15 \\
Hot air oven & 60.82 & 12.10 & 28.07 \\
\hline
\end{tabular}

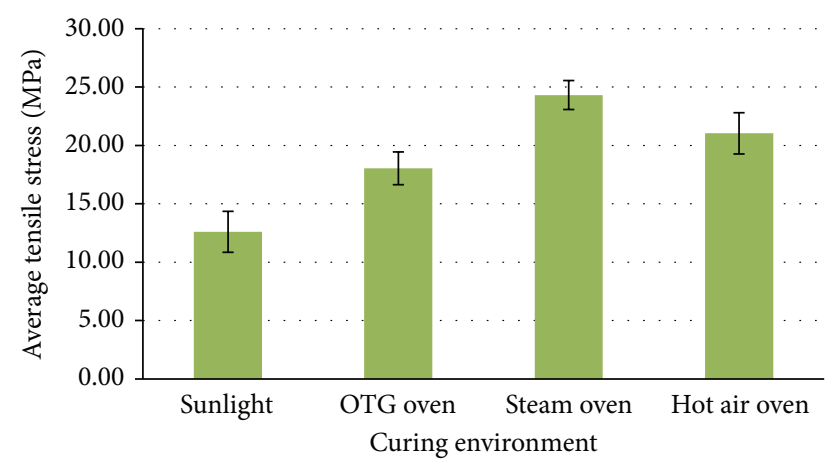

FIgURE 7: Variation of tensile stress with curing environment.

It is seen that the best tensile strength of $24.31 \mathrm{MPa}$ was obtained for laminates cured in steam oven. The increase in tensile strength when compared to laminates cured in sunlight, OTG oven, and hot air oven was of the order $93 \%, 35 \%$, and $16 \%$, respectively.

Table 6 and Figure 8 show the variation in flexural strength. Laminates cured in steam oven resulted in maximum flexural strength of $34.15 \mathrm{MPa}$. Compared to steam oven cured samples, laminates cured in sunlight, OTG oven, and hot air oven resulted in inferior results. Steam oven cured samples were $112 \%, 54 \%$, and $22 \%$ stronger in bending than sunlight cured, OTG oven cured, and hot air oven cured laminates. Flexural strength results of steam cured laminates show an improvement when compared to composites cured in similar conditions using sodium carbonate treated fibres [11].

Improved strength in case of steam oven cured laminates was due to uniform moisture removal from the composites during curing resulting in minimal distortion and shrinkage. Poor strength of sunlight cured laminates may be attributed to lower curing temperature, excessive matrix shrinkage due to nonuniform raise, and drop in atmospheric temperature and prolonged curing duration resulting in disintegration and softening of material.

\section{Conclusion}

Sodium bicarbonate concentration in the treatment solution affects the surface and strength of the areca frond fibre. Lower concentration of sodium bicarbonate had minimal effect on the strength of the frond fibres. Increase in concentration to $1 \mathrm{M}$ led to increase in surface roughness but weakened the fibre. Steam curing resulted in improved tensile and flexural strength of the composite when compared to other curing

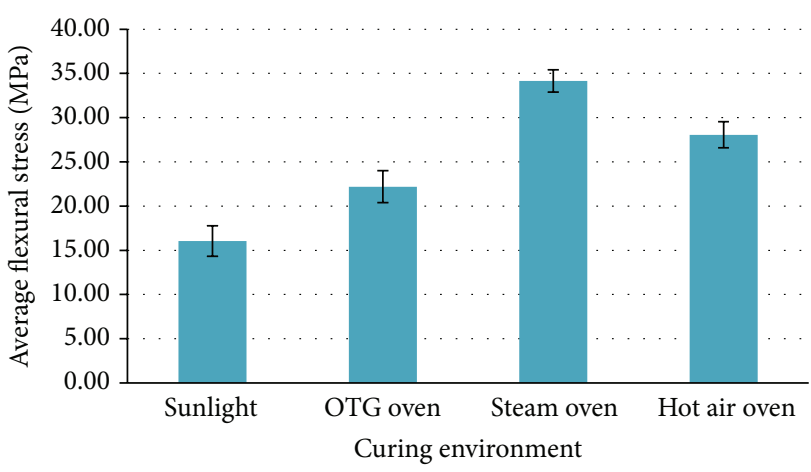

FIGURE 8: Variation of flexural stress with curing environment.

environments. Sunlight curing resulted in lower tensile and flexural strength of the composites. From the results, the strength of the composites followed the order of steam curing $>$ hot air oven curing $>$ OTG oven curing $>$ sunlight curing.

\section{Conflict of Interests}

The authors declare that there is no conflict of interests regarding the publication of this paper.

\section{Acknowledgments}

The authors are indebted to Dr. Divakara Shetty S., Head of the Department of Mechanical and Manufacturing Engineering, for permitting them to make use of the Advanced Material Testing and Research Laboratory. The authors are grateful to Dr. B. Satish Shenoy, Head of the department, and Dr. Dayanand Pai, Professor, Department of Aeronautical and Automobile Engineering, for allowing them to use Advanced Composite and Material Testing Laboratory. The authors thank Manipal College of Dental Sciences, Manipal, for permitting them to use material testing facilities. The authors would also like to thank Dr. Raghuvir Pai B., Professor, Department of Mechanical and Manufacturing Engineering, for his motivation, support, and expert guidance throughout the research work. The authors are grateful to Mr. Rohidas Pai, Chairman, Mahalasa Cashew Exports, Hiriyadka, for providing resources for curing the composites. The authors are also grateful to Mr. Harsh Agarwal and Mr. K. Sivabhushan Reddy for their support in executing this research work.

\section{References}

[1] K. K. Autar, Mechanics of Composite Materials, CRC Press, Boca Raton, Fla, USA, 2005.

[2] J.-P. Immarigeon, R. T. Holt, A. K. Koul, L. Zhao, W. Wallace, and J. C. Beddoes, "Lightweight materials for aircraft applications," Materials Characterization, vol. 35, no. 1, pp. 41-67, 1995.

[3] S. Y. Nayak, H. S. Shenoy, U. S. Rao, K. Narang, and K. V. Pant, "Mechanical properties of multi layer plain weave and 3-D glass fabric epoxy composites," International Journal of Composite Materials, vol. 5, no. 2, pp. 30-36, 2015. 
[4] J. Sahari and S. M. Sapuan, "Natural fibre reinforced biodegradable polymer composites," Reviews on Advanced Materials Science, vol. 30, no. 2, pp. 166-174, 2012.

[5] N. Srinivasababu, K. Murali Mohan Rao, and J. Suresh Kumar, "Experimental determination of tensile properties of okra, sisal and banana fiber reinforced polyester composites," Indian Journal of Science and Technology, vol. 2, no. 7, pp. 35-38, 2009.

[6] T. Nishino, K. Hirao, M. Kotera, K. Nakamae, and H. Inagaki, "Kenaf reinforced biodegradable composite," Composites Science and Technology, vol. 63, no. 9, pp. 1281-1286, 2003.

[7] S. Ochi, "Mechanical properties of kenaf fibers and kenaf/PLA composites," Mechanics of Materials, vol. 40, no. 4-5, pp. 446452, 2008.

[8] R. P. Swamy, G. C. M. Kumar, Y. Vrushabhendrappa, and V. Joseph, "Study of areca-reinforced phenol formaldehyde composites," Journal of Reinforced Plastics and Composites, vol. 23, no. 13, pp. 1373-1382, 2004.

[9] D. Zhang, K. Chen, L. Wu, D. Wang, and S. Ge, "Synthesis and characterization of PVA-HA-silk composite hydrogel by orthogonal experiment," Journal of Bionic Engineering, vol. 9, no. 2, pp. 234-242, 2012.

[10] J. Qiao, F. Du, M. Pang, M. Xiao, S. Wang, and Y. Meng, "Fabrication and properties of degradable PPC/EVOH/starch/ $\mathrm{CaCO}_{3}$ composite," Journal of Wuhan University of TechnologyMaterials Science, vol. 23, no. 3, pp. 362-366, 2008.

[11] S. S. Heckadka, M. V. Kini, R. P. Ballambat, S. S. Beloor, S. R. Udupi, and U. A. Kini, "Flexural strength analysis of starch based biodegradable composite using areca frond fibre reinforcement," International Journal of Manufacturing Engineering, vol. 2014, Article ID 769012, 6 pages, 2014.

[12] K. Majdzadeh-Ardakani and B. Nazari, "Improving the mechanical properties of thermoplastic starch/poly(vinyl alcohol)/clay nanocomposites," Composites Science and Technology, vol. 70, no. 10, pp. 1557-1563, 2010.

[13] G. T. Mahesh, B. S. Shenoy, N. H. Padmaraj, and K. N. Chethan, "Synthesis and mechanical characterization of Grewia serrulata short natural fiber composites," International Journal of Current Engineering and Technology, vol. 2, pp. 43-46, 2014.

[14] N. H. Padmaraj, M. V. Kini, B. R. Pai, B. S. Shenoy, and Krishnamoorthy, "Effect of different treatment media on the breaking strength of long Areca nut fibers," in Proceedings of the 4th National Conference on Trends in Mechanical Engineering (TIME '10), pp. 30-33, 2010.

[15] H. Srinivas Shenoy, S. Y. Nayak, Y. V. Gupta, R. Chowgule, and B. Kapil Bharadwaj, "Analysis of a forming press for composite panel fabrication," International Journal of Core Engineering \& Management, vol. 1, no. 12, pp. 185-192, 2015.

[16] ASTM, "Standard test method for tensile strength and young's modulus of fibers," ASTM C1557-14, ASTM International, West Conshohocken, Pa, USA, 2014.

[17] E. M. Fernandes, J. F. Mano, and R. L. Reis, "Hybrid corkpolymer composites containing sisal fibre: morphology, effect of the fibre treatment on the mechanical properties and tensile failure prediction," Composite Structures, vol. 105, pp. 153-162, 2013.

[18] ASTM International, ASTM D3039/D3039M-14, Standard Test Method for Tensile Properties of Polymer Matrix Composite Materials, ASTM International, West Conshohocken, Pa, USA, 2014, http://www.astm.org/.

[19] ASTM, "Standard test methods for flexural properties of unreinforced and reinforced plastics and electrical insulating materials," ASTM D790-10, ASTM International, West Conshohocken, Pa, USA, 2010.

[20] T. Alsaeed, B. F. Yousif, and H. Ku, "The potential of using date palm fibres as reinforcement for polymeric composites," Materials \& Design, vol. 43, pp. 177-184, 2013.

[21] T. H. Nam, S. Ogihara, N. H. Tung, and S. Kobayashi, "Effect of alkali treatment on interfacial and mechanical properties of coir fiber reinforced poly(butylene succinate) biodegradable composites," Composites Part B: Engineering, vol. 42, no. 6, pp. 1648-1656, 2011.

[22] M. M. Kabir, H. Wang, K. T. Lau, F. Cardona, and T. Aravinthan, "Mechanical properties of chemically-treated hemp fibre reinforced sandwich composites," Composites Part B: Engineering, vol. 43, no. 2, pp. 159-169, 2012. 

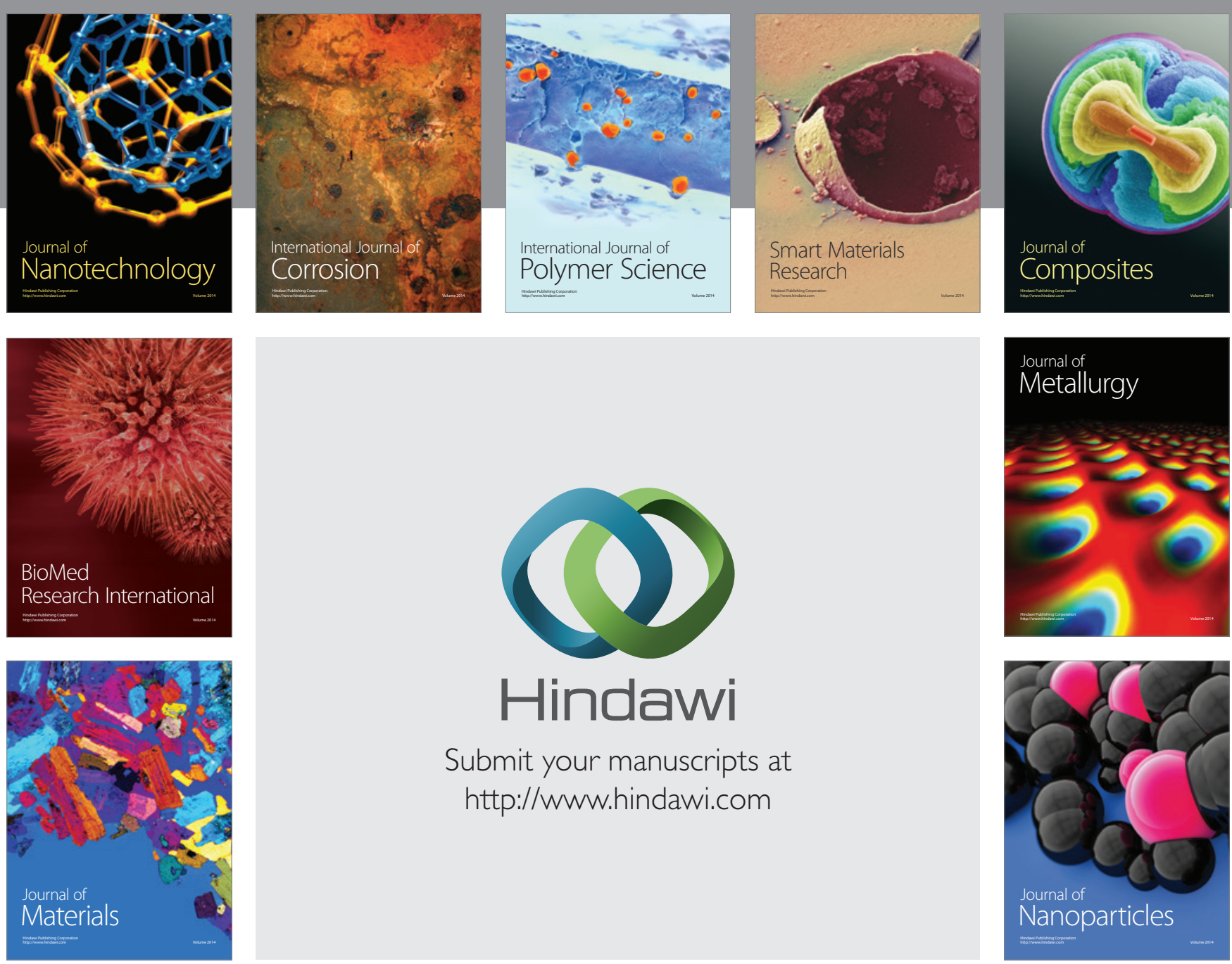

Submit your manuscripts at http://www.hindawi.com
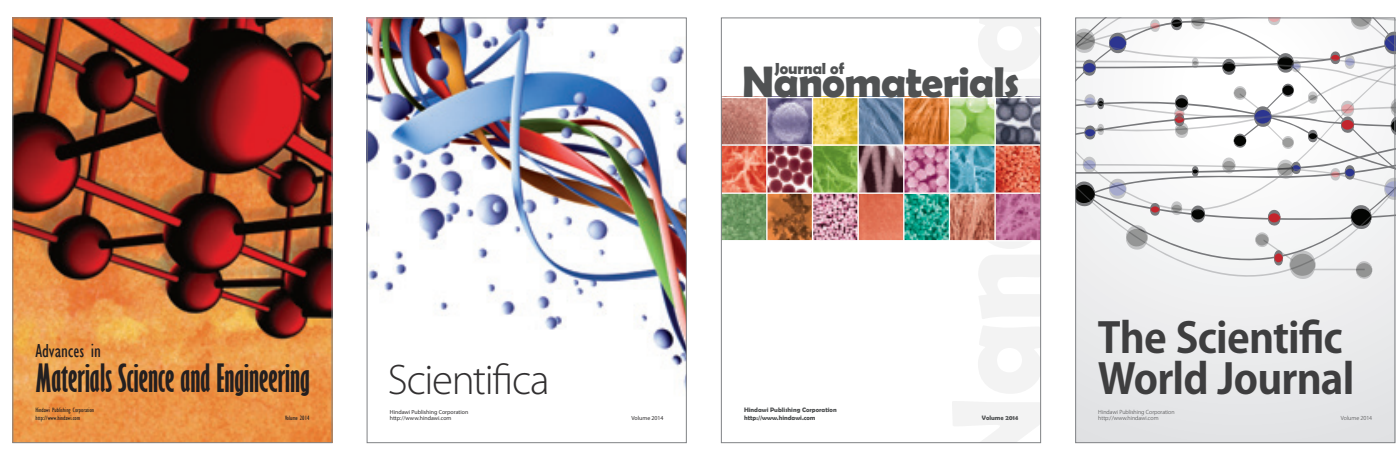

\section{The Scientific World Journal}
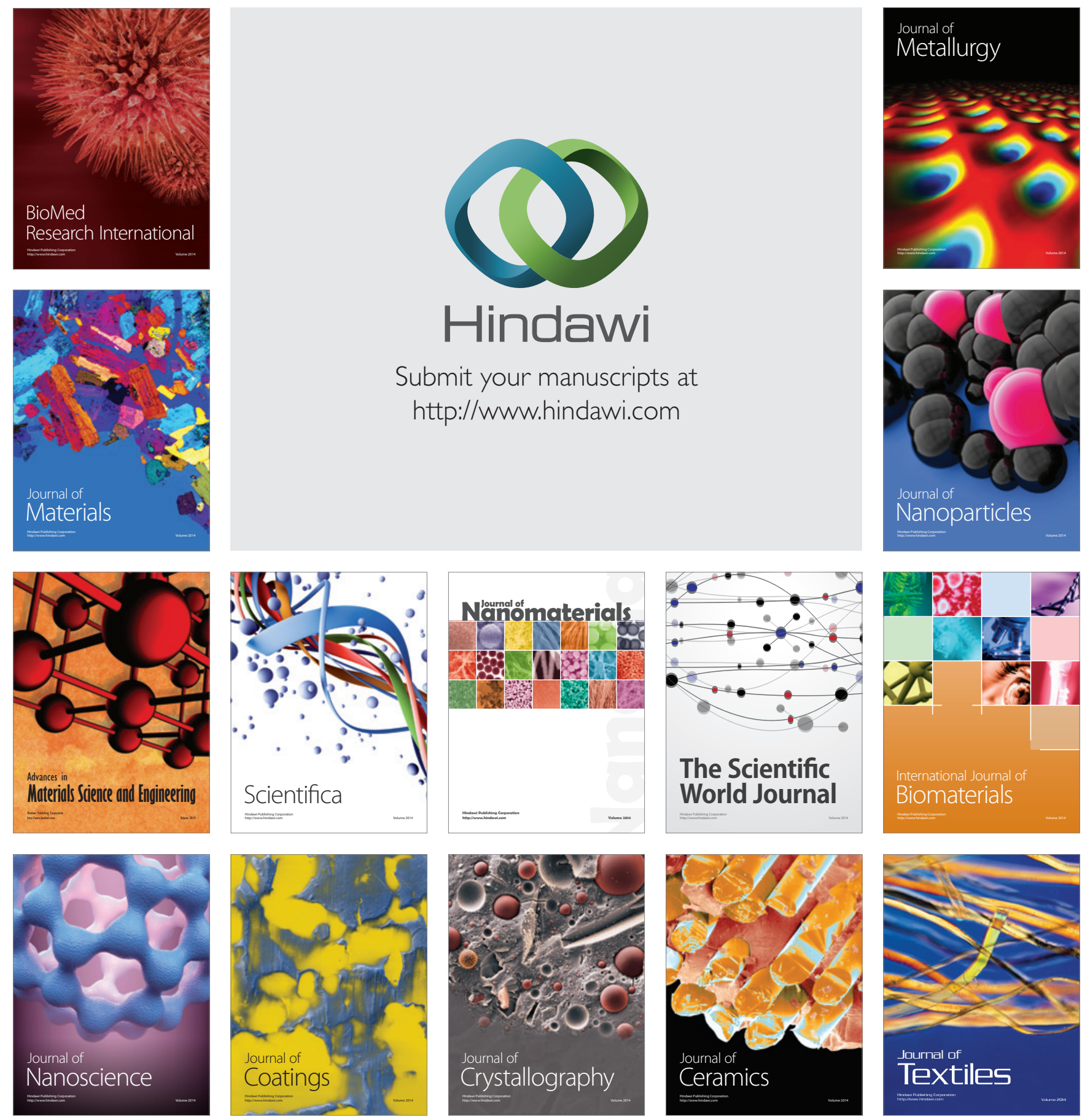